\title{
Real-World Data of Off-Label Drug Use in Patients with Actionable Genomic Alterations on Next-Generation Sequencing
}

Gabriel Roman Souza ( $\sim$ romansouza@uthscsa.edu)

University of Texas UTHSCSA: The University of Texas Health Science Center at San Antonio https://orcid.org/0000-0001-5498-2351

Ahmed Abdalla

University of Texas UTHSCSA: The University of Texas Health Science Center at San Antonio

Sukeshi Patel Arora

University of Texas UTHSCSA: The University of Texas Health Science Center at San Antonio

Daruka Mahadevan

University of Texas UTHSCSA: The University of Texas Health Science Center at San Antonio

\section{Research Article}

Keywords: off-label drug use, next-generation sequencing, immune checkpoint inhibitors, pembrolizumab, nivolumab, cancer drugs

Posted Date: December 30th, 2021

DOI: https://doi.org/10.21203/rs.3.rs-1138772/v1

License: (9) (1) This work is licensed under a Creative Commons Attribution 4.0 International License. Read Full License 


\section{Abstract}

We analyzed the outcomes of patients in our institution treated with off-label drugs targeting actionable genomic alteration based on next-generation sequencing when clinical trials were not available. Our study endpoint was objective tumor response or stable disease at 16 weeks or later after treatment initiation. Sixteen patients were included in this study, 8 were treated with immune checkpoint inhibitors targeting PD-L1 or TP53 mutations and 8 with other drugs. Tumors were analyzed based on PD-L1 expression, TP53 mutation, MSI, TMB, MMR status, and other targetable alterations. Of the 16 patients in the intention-to-treat group, no patients had an objective response after 16 weeks. Eleven patients met the primary study endpoint with stable disease, 8 in the immune checkpoint inhibitors group and 3 in the non-immune checkpoint inhibitors group. Using the log-rank test, the p-value for the difference between groups was 0.008 . In this study with off-label drugs, immune checkpoint inhibitors targeting TP53 mutations or PD-L1 expression were superior to the other drugs. This suggests the possibility of off-label use of anti-cancer drugs based on next-generation sequencing to be beneficial for advanced cancer patients without other therapeutic options.

\section{Introduction}

When standard treatment for advanced malignancies fails, and clinical trial enrollment is not an option, many oncologists consider drugs that target actionable genomic alterations. This study addressed the cases in our institution in which drugs were used in situations not currently approved by the United States Federal Drug Administration (FDA), also known as off-label use. Information is scarce in the literature, and it is unclear if this practice is beneficial to patients.

The American Society of Clinical Oncology's (ASCO's) Targeted Agent and Profile Utilization Registry (TAPUR) study is a prospective non-randomized clinical trial that is being conducted involving the off-label use of 19 drugs [1]. Our study, in comparison, is retrospective and observational, addressing a variety of offlabel drugs used in our institution when clinical trials were not available. We used similar study endpoints and definitions.

Pembrolizumab, a humanized monoclonal immunoglobulin G4 antibody directed against human cell surface receptor PD-1 (programmed death-1 or programmed cell death-1) with potential immune checkpoint inhibitory and antineoplastic activities, was the most often drug used off-label. It is approved by the FDA for the treatment of adult and pediatric patients with unresectable or metastatic tumor mutational burden-high (TMB-H) $\geq 10$ mutations/megabase (mut/Mb)] solid tumors and Microsatellite Instability-High (MSI-H) or Microsatellite Stable (MSS), and Mismatch Repair Deficient (MMRd) cancers that have progressed following prior treatment and who have no satisfactory alternative treatment options. It is also approved for many other malignancies when specific criteria are met.

Our objective was to analyze the outcomes of patients treated with off-label drugs for various solid tumors based on Next-Generation Sequencing (NGS) in our institution.

\section{Methods}

We searched our databases from Jan 1, 2020, to Jun 30, 2021, for patients who underwent comprehensive genomic profiling. Inclusion criteria were patients no longer responding to standard anti-cancer treatment or for whom no acceptable standard treatment was available and that elected to receive targeted treatment with off-label drugs for actionable genomic alterations. We also asked oncologists in our cancer center if they had patients that met these parameters. The data was analyzed on Nov 29, 2021, when all patients completed 16 weeks since starting treatment.

Caris-Molecular Intelligence (Irving, TX, USA) and Guardant360 (Redwood City, CA, USA) were the platforms used for Next Generation Sequencing (NGS) analysis. Since pembrolizumab was the most common drug used, we investigated if it would consistently reach our study endpoint in tumors with PD-L1 expression or TP53 mutations when TMB was inferior to 10 mut/Mb, MSI-H was not detected or MSS, and MMR was proficient. Objective tumor response or stable disease at 16 weeks (112 days) or later (SD16+) after treatment initiation were the primary study endpoints based on the Response Evaluation Criteria in Solid Tumors (RECIST) version 1.1. We also assessed patients for treatment-related high grade and serious adverse events (SAE), progression-free survival (PFS), and overall survival (OS) within our timeline. PFS was defined as the time from the first treatment dose to radiographic or clinical progression or death from any cause. OS was defined as the time from the first dose of treatment to death from any cause. High grade and serious adverse events were considered when related to the drug and grade 3 or higher according to the National Cancer Institute Common Terminology Criteria for Adverse Events (version 5.0). Progression-free survival and overall survival were evaluated using the Kaplan-Meier method. All analyses and plots were done utilizing IBM SPSS version 26, and a p-value $<0.05$ was considered significant.

\section{Results}

Off-label drug use based on NGS was rare in our institution when applying our strict criteria. Typically, patients who underwent NGS with advanced cancers for whom no acceptable standard treatment was available, and clinical trial enrollment was not an option, were referred to one of our oncologists, a specialist in precision oncology. Sixteen patients were included in the study. The median age was 64 years (range $20-84$ years), $68.75 \%$ were males, and $31.25 \%$ were females. $18.75 \%$ of patients had an ECOG PS of 2, 68.75\% of 1, and $12.5 \%$ of 0 . Most patients had stage IV cancer, 12 of 14 (85.71\%), 2 had cancers that did not have a staging system established but were considered advanced by the oncologist. Most patients were pre-treated with at least 2 drugs, 12 of 16 ( $75 \%$ ). All tumors were MMR proficient and MSI-H was not detected or MSS. TMB was less than 10 (low) in 14 of 16 (87.5\%) patients. TP53 mutations were found in $62.5 \%$ of tumors and PD-L1 expression in 37.5\%. Detailed demographic and clinical characteristics are listed in Table 1. 
Table 1

Baseline patient characteristics

\begin{tabular}{|c|c|}
\hline Age at diagnosis, median (range), y & 64 years $(20-84)$ \\
\hline \multicolumn{2}{|l|}{ Total patients } \\
\hline Male & $11(68.75 \%)$ \\
\hline Female & $5(31.25 \%)$ \\
\hline \multicolumn{2}{|l|}{ Race } \\
\hline White & $13(81.25 \%)$ \\
\hline Black & $3(18.75 \%)$ \\
\hline \multicolumn{2}{|l|}{ Ethnicity } \\
\hline Hispanic or Latino & $10(62.5 \%)$ \\
\hline $\begin{array}{l}\text { Non-Hispanic or } \\
\text { non-Latino }\end{array}$ & $6(37.5 \%)$ \\
\hline \multicolumn{2}{|l|}{ ECOG Performance Status } \\
\hline 0 & $2(12.5 \%)$ \\
\hline 1 & $11(68.75 \%)$ \\
\hline 2 & $3(18.75 \%)$ \\
\hline \multicolumn{2}{|c|}{ Number of patients with prior systemic therapies } \\
\hline 0 & $2(12.5 \%)$ \\
\hline 1 & $2(12.5 \%)$ \\
\hline 2 & $5(31.25 \%)$ \\
\hline$\geq 3$ & $7(43.7 \%)$ \\
\hline High grade and serious adverse events & $1(6.25 \%)$ \\
\hline PD-L1 expression & $7(43.75 \%)$ \\
\hline TP53 mutation & $10(62.5 \%)$ \\
\hline PD-L1 + TP53 & $3(18.75 \%)$ \\
\hline MSI-H not detected & $16(100 \%)$ \\
\hline MMR proficient & $16(100 \%)$ \\
\hline \multicolumn{2}{|l|}{ TMB } \\
\hline Low (0-10 mut/mb) & $14(87.5 \%)$ \\
\hline High ( $\geq 10$ mut/mb) & $2(12.5 \%)$ \\
\hline
\end{tabular}

Pembrolizumab was the most common drug used, 7 of 16 (43.75\%) cases. Other targeted therapies included: nivolumab, alpelisib, ado-trastuzumab emtansine, trastuzumab plus pertuzumab, everolimus, trematinib, olaparib, talazoparib. Detailed drug use and indications are listed in Table 2. 
Table 2

- Off-Label drug use, disease profile, and survival. The "+" sign indicates that the patient continued on treatment (PFS) or was alive (OS) after 16

\begin{tabular}{|c|c|c|c|c|c|c|c|c|c|c|c|}
\hline Age & $\begin{array}{l}\text { ECOG } \\
\text { PS }\end{array}$ & Cancer & Stage & $\begin{array}{l}\text { Off-label } \\
\text { therapy }\end{array}$ & $\begin{array}{l}\text { Mechanism } \\
\text { of action }\end{array}$ & $\begin{array}{l}\text { Gene } \\
\text { targeted }\end{array}$ & $\underset{H}{M S I-}$ & MMRd & $\begin{array}{l}\text { TMB } \\
\text { (mut/mb) }\end{array}$ & $\begin{array}{l}\text { TP53 } \\
\text { mutation }\end{array}$ & $\begin{array}{l}\text { PD-L1 } \\
\text { expressic }\end{array}$ \\
\hline 71 & 1 & $\begin{array}{l}\text { Anaplastic } \\
\text { carcinoma of the } \\
\text { thyroid }\end{array}$ & IV & Pembrolizumab & $\begin{array}{l}\text { PD-1 } \\
\text { pathway } \\
\text { blocker }\end{array}$ & $\begin{array}{l}\text { TP53 } \\
\text { mutation }\end{array}$ & no & no & low & TP53 R248Q & no \\
\hline 46 & 0 & $\begin{array}{l}\text { Thymic } \\
\text { carcinoma }\end{array}$ & IV & Pembrolizumab & $\begin{array}{l}\text { PD-1 } \\
\text { pathway } \\
\text { blocker }\end{array}$ & $\begin{array}{l}\text { PD-L1 } \\
\text { expression }\end{array}$ & no & no & 5 & no & $70 \%$ \\
\hline 65 & 1 & $\begin{array}{l}\text { Follicular } \\
\text { Thyroid } \\
\text { Carcinoma }\end{array}$ & IV & Pembrolizumab & $\begin{array}{l}\text { PD-1 } \\
\text { pathway } \\
\text { blocker }\end{array}$ & $\begin{array}{l}\text { TP53 } \\
\text { mutation } \\
\text { and PD-L1 } \\
\text { expression }\end{array}$ & no & no & 1 & $\begin{array}{l}\text { TP53 } \\
\text { E271V/K132N }\end{array}$ & $80 \%$ \\
\hline 67 & 1 & $\begin{array}{l}\text { Parotid gland } \\
\text { carcinoma }\end{array}$ & IV & Alpelisib & $\begin{array}{l}\text { PI3K } \\
\text { inhibitor }\end{array}$ & $\begin{array}{l}\text { PIK3CA } \\
\text { H1074R } \\
(12.3 \%)\end{array}$ & no & no & 20 & $\begin{array}{l}\text { TP53 } \\
\text { E271V/K132N, } \\
K 139 N, R 175 H\end{array}$ & no \\
\hline 53 & 2 & $\begin{array}{l}\text { Adenocarcinoma } \\
\text { of the lung }\end{array}$ & IV & $\begin{array}{l}\text { Ado- } \\
\text { trastuzumab } \\
\text { emtansine }\end{array}$ & $\begin{array}{l}\text { HER2 } \\
\text { suppression }\end{array}$ & HER-2 & no & no & 1 & no & no \\
\hline 44 & 0 & $\begin{array}{l}\text { Adrenal Cortical } \\
\text { Carcinoma }\end{array}$ & IV & Trametinib & $\begin{array}{l}\text { MEK } \\
\text { inhibitor }\end{array}$ & $\begin{array}{l}\text { NF-1 Exon } \\
21 \text { p.L828 }\end{array}$ & no & no & 3 & $\begin{array}{l}\text { TP53 Exon } 6 \\
\text { p.N210fs }\end{array}$ & no \\
\hline 84 & 1 & $\begin{array}{l}\text { Papillary Thyroid } \\
\text { Carcinoma }\end{array}$ & IV & Pembrolizumab & $\begin{array}{l}\text { PD-1 } \\
\text { pathway } \\
\text { blocker }\end{array}$ & $\begin{array}{l}\text { TP53 } \\
\text { mutation }\end{array}$ & no & no & 1.94 & $\begin{array}{l}\text { TP53 } \\
\text { G244C/G245I, } \\
\text { N131I, M237V }\end{array}$ & no \\
\hline 57 & 1 & $\begin{array}{l}\text { Squamous Cell } \\
\text { Carcinoma of } \\
\text { the Lung }\end{array}$ & III & Everolimus & $\begin{array}{l}\text { mTOR } \\
\text { inhibitor }\end{array}$ & $\begin{array}{l}\text { NFE2L2 } \\
\text { p.D27Y }\end{array}$ & no & no & 7 & $\begin{array}{l}\text { TP53 } \\
\text { p.1255del }\end{array}$ & no \\
\hline 77 & 2 & $\begin{array}{l}\text { Squamous Cell } \\
\text { Carcinoma of } \\
\text { unknown } \\
\text { primary site }\end{array}$ & & Pembrolizumab & $\begin{array}{l}\text { PD-1 } \\
\text { pathway } \\
\text { blocker }\end{array}$ & $\begin{array}{l}\text { TP53 } \\
\text { mutation } \\
\text { and PD-L1 } \\
\text { expression }\end{array}$ & no & no & 4 & $\begin{array}{l}\text { TP53 R282G, } \\
\text { C238Y }\end{array}$ & CPS:30 \\
\hline 20 & 1 & $\begin{array}{l}\text { Parotid } \\
\text { Adenocarcinoma }\end{array}$ & III & Olaparib & $\begin{array}{l}\text { PARP1/2 } \\
\text { inhibitor }\end{array}$ & $\begin{array}{l}\text { ARID1A } \\
\text { A165fs }\end{array}$ & no & no & low & no & no \\
\hline 79 & 1 & $\begin{array}{l}\text { Adenocarcinoma } \\
\text { of the lung }\end{array}$ & IV & Everolimus & $\begin{array}{l}\text { mTOR } \\
\text { inhibitor }\end{array}$ & STK11 E199 & no & no & $\begin{array}{l}7 \\
\text { mut/mb }\end{array}$ & no & no \\
\hline 76 & 1 & $\begin{array}{l}\text { Anaplastic } \\
\text { carcinoma of the } \\
\text { thyroid }\end{array}$ & IV & Pembrolizumab & $\begin{array}{l}\text { PD-1 } \\
\text { pathway } \\
\text { blocker }\end{array}$ & $\begin{array}{l}\text { TP53 } \\
\text { mutationand } \\
\text { PD-L1 } \\
\text { expression }\end{array}$ & no & no & $\begin{array}{l}8 \\
\text { mut } / \mathrm{mb}\end{array}$ & $\begin{array}{l}\text { TP53 } \\
\text { A138_Q144del }\end{array}$ & $5 \%$ \\
\hline 64 & 1 & $\begin{array}{l}\text { Squamous cell } \\
\text { carcinoma of the } \\
\text { tonsil }\end{array}$ & IV & Talazoparib & $\begin{array}{l}\text { PARP1/2 } \\
\text { inhibitor }\end{array}$ & CHEK2 E239 & no & no & $\begin{array}{l}4 \\
\text { mut/mb }\end{array}$ & $\begin{array}{l}\text { TP53 } \\
\text { S127F/R273H }\end{array}$ & CPS:20 \\
\hline 79 & 1 & $\begin{array}{l}\text { Extramammary } \\
\text { Paget's disease } \\
\text { of the penis and } \\
\text { scrotum }\end{array}$ & & Pembrolizumab & $\begin{array}{l}\text { PD-1 } \\
\text { pathway } \\
\text { blocker }\end{array}$ & $\begin{array}{l}\text { PD-L1 } \\
\text { expression }\end{array}$ & no & no & $\begin{array}{l}7 \\
\text { mut/mb }\end{array}$ & no & CPS:20 \\
\hline 42 & 1 & Rectal cancer & IV & $\begin{array}{l}\text { Trastuzumab } \\
\text { plus } \\
\text { Pertuzumab }\end{array}$ & $\begin{array}{l}\text { HER2 } \\
\text { suppression }\end{array}$ & $\begin{array}{l}\text { ERBB2 } \\
\text { high(+++) }\end{array}$ & no & no & $\begin{array}{l}13.4 \\
\mathrm{mut} / \mathrm{mb}\end{array}$ & $\begin{array}{l}\text { TP53 } \\
\text { Y205D/R213fs }\end{array}$ & no \\
\hline 62 & 2 & $\begin{array}{l}\text { Gallbladder } \\
\text { adenocarcinoma }\end{array}$ & IV & Nivolumab & $\begin{array}{l}\text { PD-1 } \\
\text { pathway } \\
\text { blocker }\end{array}$ & $\begin{array}{l}\text { PD-L1 } \\
\text { expression }\end{array}$ & no & no & $\begin{array}{l}8 \\
\text { mut } / \mathrm{mb}\end{array}$ & no & $15 \%$ \\
\hline
\end{tabular}

Of the 16 patients in the intention-to-treat group, no patients had an objective response after 16 weeks. Eleven (69.75\%) patients met the primary study endpoint of PFS of at least 16 weeks or 112 days. All 8 patients who received off-label immune checkpoint inhibitors (ICI) to target PD-L1 or TP53 mutations had SD16+. The other drugs that met the primary endpoint were trastuzumab plus pertuzumab, everolimus, and trametinib. In the non-immune checkpoint inhibitors (non-ICl) group, only 3 of $8(37.5 \%)$ met the study's primary endpoints. There was a significant difference between ICl and non-ICl-treated patients ( $\mathrm{p}$ $=0.008$ ). A single grade 3 adverse event of diarrhea was reported due to the use of alpelisib. In a per-protocol analysis excluding alpelisib, the difference was also significant $(\mathrm{p}=0.014)$.

\section{Discussion}

A study at MD Anderson at Cooper showed that out of 305 consecutive NGS assays, only 6 patients started off-label therapies (2\%) based on the assay result, and they had a poor prognosis [2]. However, in our study the off-label use of ICls, when targeting PD-L1 expression or TP53 mutations, consistently met our 
primary endpoint of stable disease at 16 weeks or later. This finding is consistent with previous studies that demonstrated that PD-L1 and TP53 mutations predict response to ICls.

A phase 1, non-randomized clinical trial involving 475 patients with 20 types of cancers demonstrated that patients with advanced solid tumors expressing PD-L1 had a higher response rate to pembrolizumab independently of TMB [3]. In addition, a phase 3 randomized, open-label clinical trial with 305 patients with locally advanced or metastatic non-small lung cancer showed that pembrolizumab monotherapy was superior to chemotherapy in adult patients with a PD-L1 TPS of $50 \%$ or greater [4], and another clinical trial with 1274 participants concluded superiority with a PD-L1 TPS of 1\% or more [5]. These and other studies led to the FDA approval of pembrolizumab for NSCLC, HNSCC, gastric cancer, esophageal cancer, cervical cancer, and triple-negative breast cancer with different PD-L1 expression thresholds. A study with 72 patients with advanced NSCLC patients treated with programmed death-1 blockers showed higher overall survival in the TP53 mutated group than in the non-mutated group [6]. Other studies with TP53 mutated tumors showed mixed results to immune checkpoint inhibitors and likely different responses of the various TP53 mutations $[7,8,9]$.

To characterize off-label use of pembrolizumab we excluded tumors with MSI-H/MSS, MMRd, or TMB $\geq 10$ mut/mb. The most compelling data for its use in these cases was established in KEYNOTE-158. This phase 2 clinical trial enrolled 1595 patients [10] with 27 different tumor types with a median follow-up of 13.4 months. Patients received pembrolizumab $200 \mathrm{mg}$ IV every three weeks. 233 patients were evaluable for MSI-H/MMRd. The objective response rate (ORR) was $34.3 \%$ and $86.9 \%$ had a response duration of 12 months or longer [11]. 805 patients were evaluable for TMB, 105 had a TMB $\geq 10$ mut/mb. The ORR was $29 \%$ for TMB high patients versus $6 \%$ for TMB low [12].

To our knowledge, no studies have simultaneously analyzed PD-L1 expression, TP53 mutation, MSI, TMB, and MMR status across various tumors with the use of off-label ICls versus non-ICls. We also addressed tumors not commonly present on these analyses: papillary, follicular, anaplastic thyroid carcinomas, extramammary Paget's disease of the scrotum, and squamous cell carcinoma of an unknown primary site. Despite the small sample size, the difference between groups was significant suggesting that ICls may be beneficial in patients with PD-L1 expression or TP53 mutation in the setting of MSS or MSI-H not detected, TMB $<10 \mathrm{mut} / \mathrm{mb}$, and MMR proficient tumors not currently FDA approved. This suggests the possibility that off-label use of certain cancer drugs based on NGS may be beneficial for patients without other options of treatment.

This study has limitations. Our sample size was small since we were not conducting a clinical trial but analyzing cases retrospectively of real-world off-label drug use. Mutations that are not currently detected by NGS or not completely understood may have played a role in response to ICls in the different types of cancer analyzed. For example, a recent study at the MD Anderson Cancer Center with data from over 10,000 tumors included in the Cancer Genome Atlas showed that TMB does not predict response to ICls equally in different types of cancers [13]. This means that current evidence is insufficient to validate the threshold of 10 mut/Mb and the optimal limit might be higher or lower for different tumor types. Besides, the threshold for PD-L1 expression likely varies among tumors and different TP53 mutations determine a different response to ICls. Further studies are needed to validate the use of off-label drugs based on NGS, ICls in tumors with PD-L1 expression or TP53 mutations, and their interrelationship with other predictors of tumor response.

\section{Declarations}

\section{Ethics declarations}

\section{Ethics approval}

This study was performed in line with the principles of the Declaration of Helsinki. The institutional review board of the University of Texas Health San Antonio approved this study.

\section{Consent to participate}

Not applicable.

\section{Consent for publication}

Not applicable.

\section{Data availability}

We conducted an observational retrospective study. The datasets generated and analyzed were gathered from the EPIC database of the Mays Cancer Center, MD Anderson Cancer Center, University of Texas Health San Antonio and are available from the corresponding author upon reasonable request.

\section{Code availability}

Not applicable.

\section{Competing interests}

The authors declare no conflict of interest.

\section{Funding}

The authors declare that no funds, grants, or other support were received during the preparation of this manuscript. 


\section{Authors`contributions}

Gabriel Roman Souza and Daruka Mahadevan contributed to the study conception and design. Material preparation and analysis were performed by Gabriel Roman Souza. Data collection was performed by all authors. The first draft of the manuscript was written by Gabriel Roman Souza and all authors commented on previous versions of the manuscript. All authors read and approved the final manuscript.

\section{Acknowledgment}

Not applicable.

\section{Compliance with ethical standards}

\section{Disclosure of potential conflicts of interest}

The authors declare no conflict of interest.

\section{Research involving Human Participants and/or Animals}

This research involves human participants. This study was performed in line with the principles of the Declaration of Helsinki. The institutional review board of the University of Texas Health San Antonio approved this study.

\section{Informed consent}

For this type of study, formal consent is not required.

\section{References}

1. Mangat PK, Halabi S, Bruinooge SS, Garrett-Mayer E, Alva A, Janeway KA, Stella PJ, Voest E, Yost KJ, Perlmutter J, Pinto N, Kim ES, Schilsky RL (2018) Rationale and Design of the Targeted Agent and Profiling Utilization Registry (TAPUR) Study. JCO Precis Oncol 2018. 10.1200/PO.18.00122

2. Davis W, Makar G, Mehta P, Zhu GG, Somer R, Morrison J, Kubicek GJ Next-Generation Sequencing in 305 Consecutive Patients: Clinical Outcomes and Management Changes.J Oncol Pract. 2019Dec; 15(12):e1028-e1034. doi: 10.1200/JOP.19.00269

3. Ott PA, Bang YJ, Piha-Paul SA, Razak ARA, Bennouna J, Soria JC, Rugo HS, Cohen RB, O'Neil BH, Mehnert JM, Lopez J, Doi T, van Brummelen EMJ, Cristescu R, Yang P, Emancipator K, Stein K, Ayers M, Joe AK, Lunceford JK (2019) T-Cell-Inflamed Gene-Expression Profile, Programmed Death Ligand 1 Expression, and Tumor Mutational Burden Predict Efficacy in Patients Treated With Pembrolizumab Across 20 Cancers: KEYNOTE-028. J Clin Oncol. Feb 1;37(4):318-327. doi: 10.1200/JC0.2018.78.2276

4. Reck M, Rodríguez-Abreu D, Robinson AG, Hui R, Csőszi T, Fülöp A, Gottfried M, Peled N, Tafreshi A, Cuffe S, O'Brien M, Rao S, Hotta K, Leiby MA, Lubiniecki GM, Shentu Y, Rangwala R, Brahmer JR (2016 Nov) KEYNOTE-024 Investigators. Pembrolizumab versus Chemotherapy for PD-L1-Positive NonSmall-Cell Lung Cancer. N Engl J Med 10;375((19):1823-1833. doi: 10.1056/NEJMoa1606774

5. Mok TSK, Wu YL, Kudaba I, Kowalski DM, Cho BC, Turna HZ, Castro G Jr, Srimuninnimit V, Laktionov KK, Bondarenko I, Kubota K, Lubiniecki GM, Zhang J, Kush D, Lopes G ; KEYNOTE-042 Investigators. Pembrolizumab versus chemotherapy for previously untreated, PD-L1-expressing, locally advanced or metastatic non-small-cell lung cancer (KEYNOTE-042): a randomised, open-label, controlled, phase 3 trial.Lancet. 2019 May4;393(10183):1819-1830. doi: 10.1016/S0140-6736(18)32409-7

6. Assoun S, Theou-Anton N, Nguenang M, Cazes A, Danel C, Abbar B, Pluvy J, Gounant V, Khalil A, Namour C, Brosseau S, Zalcman G (2019 Jun) Association of TP53 mutations with response and longer survival under immune checkpoint inhibitors in advanced non-small-cell lung cancer. Lung Cancer 132:65-71. doi: 10.1016/j.lungcan.2019.04.005

7. Frost N, Kollmeier J, Vollbrecht C, Grah C, Matthes B, Pultermann D, von Laffert M, Lüders H, Olive E, Raspe M, Mairinger T, Ochsenreither S, Blum T, Hummel M, Suttorp N, Witzenrath M, Grohé C KRASG12C/ TP53 co-mutations identify long-term responders to first line palliative treatment with pembrolizumab monotherapy in PD-L1 high ( $\geq 50 \%$ ) lung adenocarcinoma.Transl Lung Cancer Res. 2021Feb; 10(2):737-752. doi: 10.21037/tlcr-20-958. PMID: 33718018; PMCID: PMC7947421.

8. Lyu Q, Lin A, Cao M, Xu A, Luo P, Zhang J Alterations in TP53 Are a Potential Biomarker of Bladder Cancer Patients Who Benefit From Immune Checkpoint Inhibition.Cancer Control. 2020 Jan-Dec; 27(1):1073274820976665. doi: 10.1177/1073274820976665

9. Sun H, Liu SY, Zhou JY, Xu JT, Zhang HK, Yan HH, Huan JJ, Dai PP, Xu CR, Su J, Guan YF, Yi X, Yu RS, Zhong WZ, Wu YL (2020 Oct) Specific TP53 subtype as biomarker for immune checkpoint inhibitors in lung adenocarcinoma. EBioMedicine. 60:102990.. doi: 10.1016/j.ebiom.2020.102990

10. ClinicalTrials.gov [Internet]. Bethesda (MD): National Library of Medicine (US) (2000) Feb 29 -. Identifier NCT02628067, Study of Pembrolizumab (MK3475) in Participants With Advanced Solid Tumors (MK-3475-158/KEYNOTE-158); 2015 Dec 9 [cited 2021 Dec 1]; [about 4 screens]. Available from: https://clinicaltrials.gov/ct2/show/record/NCT02628067

11. Marabelle A, Le DT, Ascierto PA, Di Giacomo AM, De Jesus-Acosta A, Delord JP, Geva R, Gottfried M, Penel N, Hansen AR, Piha-Paul SA, Doi T, Gao B, Chung HC, Lopez-Martin J, Bang YJ, Frommer RS, Shah M, Ghori R, Joe AK, Pruitt SK, Diaz LA Jr (2020) Efficacy of Pembrolizumab in Patients With Noncolorectal High Microsatellite Instability/Mismatch Repair-Deficient Cancer: Results From the Phase II KEYNOTE-158 Study. J Clin Oncol. Jan 1;38(1):1-10. doi: 10.1200/JC0.19.02105

12. Marabelle A, Fakih M, Lopez J, Shah M, Shapira-Frommer R, Nakagawa K, Chung HC, Kindler HL, Lopez-Martin JA, Miller WH Jr, Italiano A, Kao S, PihaPaul SA, Delord JP, McWilliams RR, Fabrizio DA, Aurora-Garg D, Xu L, Jin F, Norwood K, Bang YJ (2020 Oct) Association of tumour mutational burden with 
outcomes in patients with advanced solid tumours treated with pembrolizumab: prospective biomarker analysis of the multicohort, open-label, phase 2 KEYNOTE-158 study. Lancet Oncol 21(10):1353-1365. doi: 10.1016/S1470-2045(20)30445-9

13. McGrail DJ, Pilié PG, Rashid NU, Voorwerk L, Slagter M, Kok M, Jonasch E, Khasraw M, Heimberger AB, Lim B, Ueno NT, Litton JK, Ferrarotto R, Chang JT, Moulder SL, Lin SY (2021 May) High tumor mutation burden fails to predict immune checkpoint blockade response across all cancer types. Ann Oncol 32(5):661-672. doi: 10.1016/j.annonc.2021.02.006

\section{Figures}

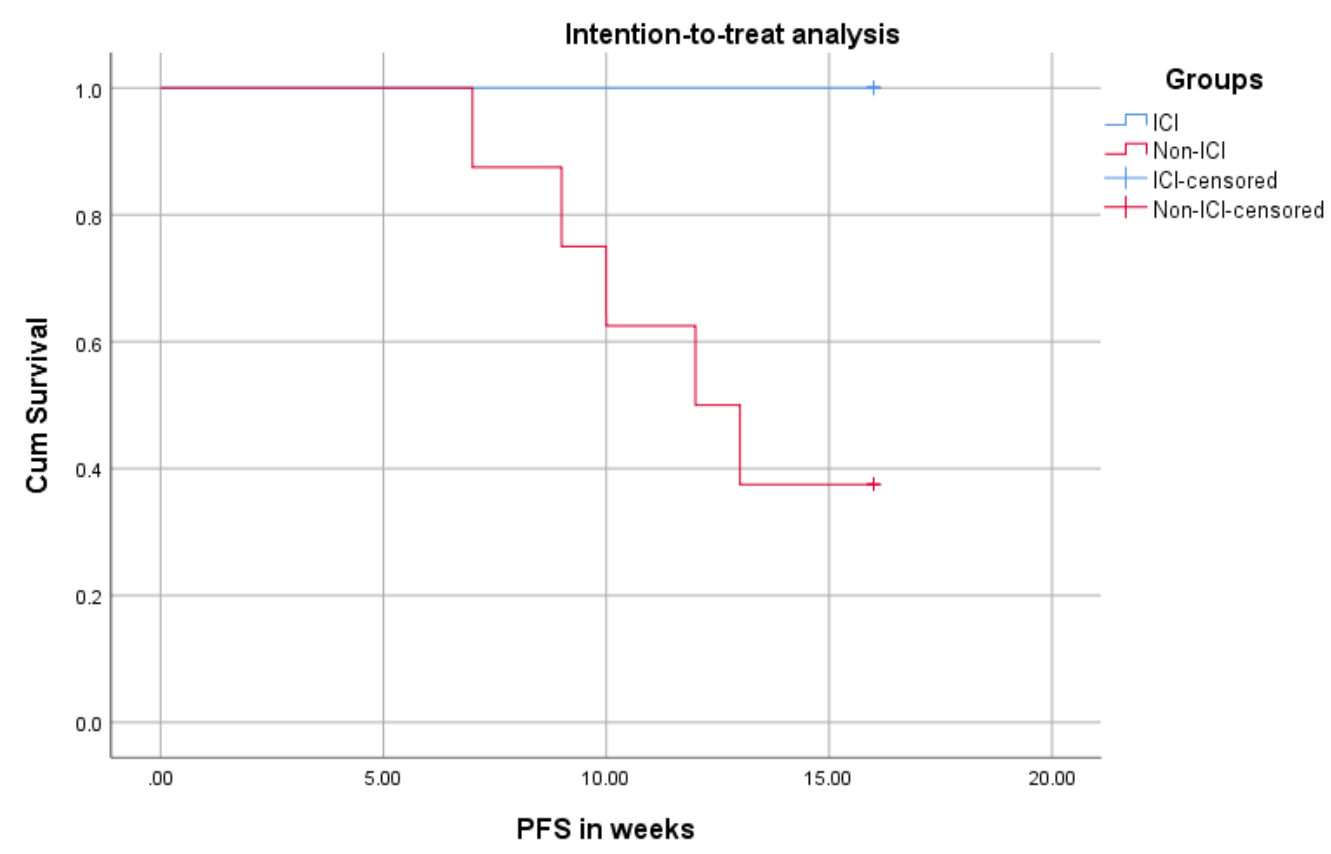

\section{Figure 1}

Kaplan-Meier curve showing the percentage of patients who met SD16+ in the off-label immune checkpoint inhibitors group and in the off-label non-immune checkpoint inhibitors group in an intention-to-treat analysis. Using the log-rank test, the p-value for the difference between groups was 0.008. 


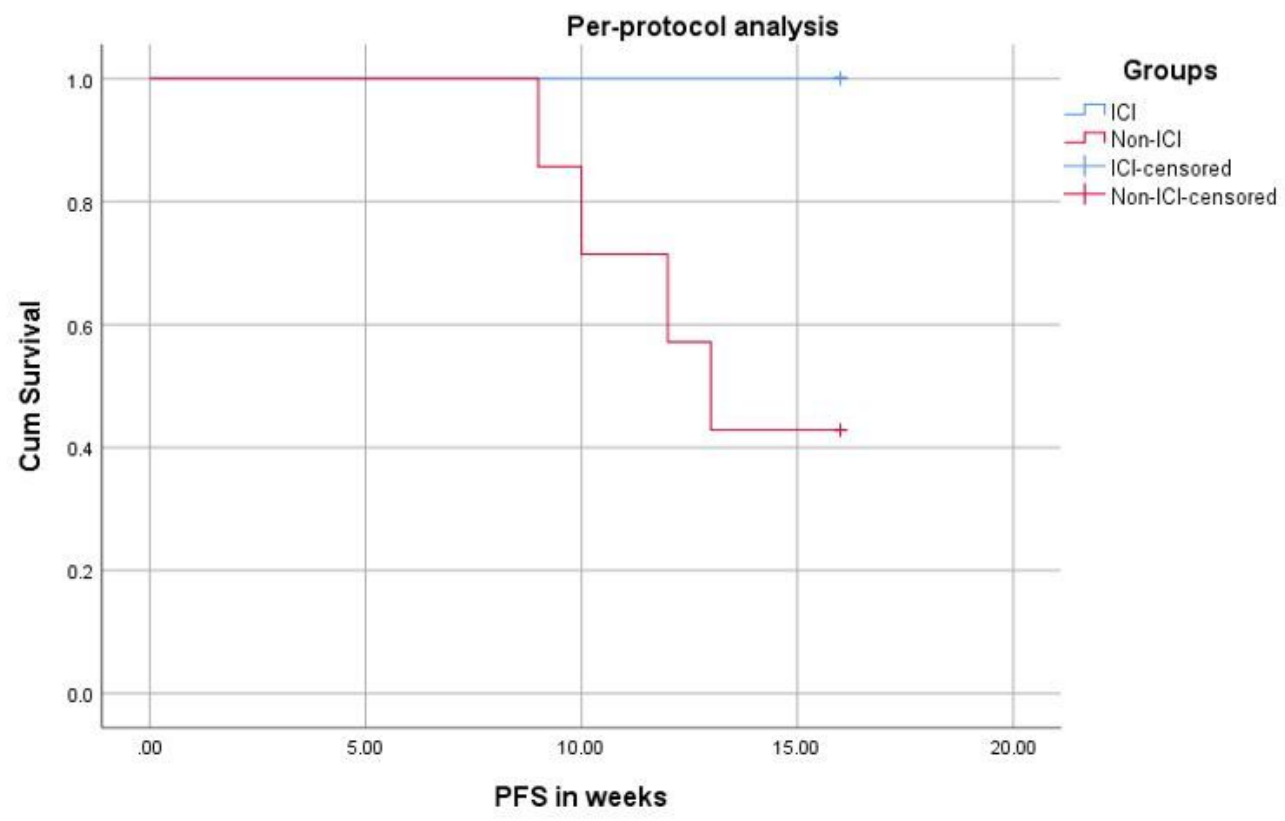

Figure 2

Kaplan-Meier curve showing the percentage of patients who met SD16+ in the off-label immune checkpoint inhibitors group and in the off-label non-immune checkpoint inhibitors group in a per-protocol analysis. Using the log-rank test, the p-value for the difference between groups was 0.014 . 